\title{
REDES DE IMIGRAÇÃO SÍRIA NO BRASIL E A CRIAÇÃO DE NOVOS NEGÓCIOS
}

\author{
${ }^{1}$ Gislene Cordeiro da Silva Diniz, Liliane de Oliveira Guimarães, Roberto Pessoa de Queiroz Falcão \& Eduardo \\ Picanço Cruz \\ Pontifícia Universidade Católica de Minas Gerais - PUC, Minas Gerais, (Brasil) \\ Universidade Federal Fluminense - UFF, Rio de Janeiro, (Brasil)
}

\begin{tabular}{l}
\hline DETALHES DO ARTIGO \\
\hline Histórico do Artigo: \\
Recebido em: 16 de agosto de 2020 \\
Aceito: 29 de março de 2021 \\
Disponível online: 27 de outubro de 2021 \\
Sistema de revisão “Double blind review” \\
Editor Científico \\
Ilan Avrichir \\
\hline Palavras-chaves: \\
Empreendedorismo de Imigrantes \\
Sírios \\
Redes Sociais
\end{tabular}

\begin{abstract}
RESUMO
Objetivo: O objetivo deste trabalho é analisar como redes étnicas apoiam e influenciam na criação de novos negócios.

Método: Pesquisa de natureza qualitativa e método de estudo de casos múltiplos. Entrevistas semiestruturadas com 24 refugiados sírios estabelecidos na cidade do Rio de Janeiro, Belo Horizonte e sua região metropolitana. As entrevistas foram realizadas entre agosto de 2017 e maio de 2019.

Principais resultados: Os resultados apontam que as redes étnicas influenciaram e disponibilizaram recursos que contribuíram com o processo empreendedor. Constatou-se a importância da atividade empreendedora para a geração de renda dos refugiados, principalmente em negócios relacionados à sua cultura de origem. Os achados confirmaram que as estruturas sociais são detentoras de um volume significativo de capital social, o qual permite o acesso a diversos tipos de recursos que promovem o processo empreendedor.
\end{abstract}

Relevância/originalidade: Este artigo contribui para o debate acerca do empreendedorismo imigrante realizado por refugiados em solo brasileiro, apontando para a importância e para os efeitos das redes sociais e do capital social no desenvolvimento de novos negócios.

Contribuições teóricas/metodológicas: Maior compreensão sobre a dinâmica local do empreendedorismo imigrante, das redes sociais e do capital social. Amplia os modelos conceituais e teóricos estabelecidos no estudo do processo empreendedor imigrante.

Contribuições sociais: Importância da atividade empreendedora de imigrantes na geração de renda e no desenvolvimento da economia local. Os achados revelam a necessidade de políticas públicas que apoiem o empreendedorismo imigrante no Brasil.

\section{Introdução}

Questões relativas à imigração são noticiadas com frequência em todo o mundo e têm se tornado alvo de preocupações em diversos países. Nesse contexto, podem-se mencionar a crise migratória na fronteira dos Estados Unidos e México - com a chegada maciça e contínua de imigrantes mexicanos, hondurenhos, e demais centro-americanos -, assim como a crise dos refugiados com destino à Europa e a diáspora dos venezuelanos para o Brasil e Colômbia. Situações como essas têm gerado importantes reflexões na sociedade atual e esta tem percebido que urge a integração social e econômica desses indivíduos, sobretudo os que emigram em condições precárias e de refúgio.

Nesse sentido, o empreendedorismo parece representar uma alternativa para promover o desenvolvimento social e econômico e estimular a integração social dos imigrantes.

De acordo com dados divulgados em 2018 pela Organização das Nações Unidas (ONU), os conflitos na Síria já duram mais que a segunda guerra mundial. 
Até os dias atuais, são sete anos de conflito, tendo o número de mortos ultrapassado 300 mil pessoas. A ONU estima que mais de sete milhões de sírios abandonaram seus lares, com aproximadamente 60\% da população vivendo abaixo da linha pobreza. O número de refugiados ultrapassa cinco milhões. No Brasil, foram mais de 120 mil solicitações de refúgio nos últimos 7 anos, sendo os sírios a quarta maior nacionalidade a buscá-lo (Brasil, 2017). Segundo Mialhe e Malheiros (2016), as organizações não governamentais exercem importante papel de apoio na recepção desses refugiados e imigrantes no Brasil e, em parceria com instituições governamentais, prestam serviços de apoio e de solicitação de refúgio visando a regularização perante os órgãos governamentais.

No entanto, esses imigrantes e refugiados enfrentam diversas barreiras para se integrarem social e economicamente na sociedade de destino. Grande parte dessas barreiras estão ligadas à falta de proficiência no idioma, à xenofobia, à falta de documentação legal que permita sua inserção no mercado formal de trabalho, à falta de experiência laboral, à escassez de recursos financeiros e à ausência de uma rede de apoio estruturada (Diniz, Guimarães, \& Fernandes, 2019; Gurău, Dana, \& Light, 2020; Neto, Versiani, Pellizari, Mota-Santos, \& Abreu, 2020).

Com tantas barreiras, muitos buscam no empreendedorismo sua sobrevivência. Conforme exposto por Coleman (1988), Correa et al. (2018) e Sandberg et al. (2019), para a concretização do empreendimento contam com o apoio de suas redes sociais locais e de redes sociais localizadas em seu país de destino. Ao acessarem o capital social existente dentro das estruturas sociais (redes sociais), são disponibilizados variados tipos de recursos materiais e simbólicos e de informações relevantes que facilitam e promovem o empreendedorismo. Ademais, estudos têm demonstrado como os negócios de imigrantes têm contribuído para movimentar a economia local e global, estimulando a competitividade e o crescimento econômico da sociedade de destino (Diniz et al., 2019; Gurău et al., 2020; Nazareno, Zhou, \& You, 2019; Zhou \& Liu, 2015).

Nesse contexto, questiona-se: Como as redes étnicas apoiam e influenciam na criação de novos negócios para imigrantes refugiados no Brasil? Para responder a essa pergunta, foi realizada uma pesquisa exploratória com vinte e quatro imigrantes e refugiados sírios nas cidades do Rio de Janeiro, Belo Horizonte e sua região metropolitana, com o objetivo de ajudar a compreender como as condições institucionais e de acolhimento do país anfitrião influenciam na tomada de decisão de criar negócios étnicos e a relação desses negócios com diferentes públicos.

Uma pesquisa recente de revisão da literatura sobre empreendedorismo de imigrantes realizada por Dabić, Vlačić, Paul, Dana, Sahasranamam e Glinka (2020) apontou as principais lacunas de pesquisa que envolvem a temática do empreendedorismo de imigrantes. Entre elas, os autores destacam a necessidade de mais pesquisas, especialmente em países emergentes, como os localizados no hemisfério sul. Sendo assim, este artigo busca contribuir para diminuir essa lacuna apontada pela literatura acadêmica.

O artigo foi estruturado da seguinte forma: após esta introdução, estabelece-se o referencial teórico que norteou a pesquisa e a análise dos dados coletados. No item 3, descreve-se a metodologia utilizada no trabalho de investigação. No item 4, apresenta-se a análise dos dados coletados e, por fim, no item 5, apresentam-se as considerações finais do trabalho.

\section{Referencial Teórico}

Nesta seção, serão abordados os fundamentos teóricos da pesquisa. Inicialmente, serão apresentados os conceitos sobre o empreendedorismo de imigrantes e refugiados; posteriormente, os conceitos e teorias sobre redes sociais e capital social que envolvem a atividade empreendedora e, por último, o modelo teórico desenvolvido pelos autores utilizado para a análise dos dados.

\subsection{Empreendedorismo de Imigrantes e de Refugiados}

Estudos sobre o empreendedorismo étnico ainda se encontram em fase embrionária. No entanto, têm despertado interesse de diversos pesquisadores, tais como Cruz, Falcão e Barreto (2018), Diniz et al. (2019), Nazareno et al. (2019), Portes e Zhou (1992, 2012), Urban (2011), Zhou (2004), entre outros. As pesquisas desses autores abordam o 
empreendedorismo étnico, como aquele realizado por imigrantes que fazem a opção por negócios ligados à sua herança cultural. Normalmente, esses empreendedores mantêm laços culturais e emocionais com coétnicos e tendem a se concentrar em um mesmo espaço geográfico formando, assim, enclaves étnicos. Já os empreendedores imigrantes são aqueles que fazem a opção por negócios presentes na economia mainstream e, ao contrário dos empreendedores étnicos, evitam manter laços emocionais com coétnicos, sempre buscando dissociar-se deles.

De acordo com Shinnar e Zamantili (2019), várias motivações levam os imigrantes ao empreendedorismo, sendo a identificação de uma oportunidade e a necessidade as principais delas. Vale, Corrêa e dos Reis (2014) concordam com essa afirmação e mencionam que muitos estudos sobre empreendedorismo exploraram, especialmente, os fatores de natureza intrínseca para explicar a motivação empreendedora. Contudo, nos últimos anos, têm-se enfatizado fatores de natureza extrínseca, tal como o desemprego. Vale et al. (2014) acrescentam que fatores intrínsecos e extrínsecos podem interagir entre si, levando os atores ao empreendedorismo. No que tange ao empreendedorismo de imigrantes, os pesquisadores Haas (2011) e Zhou (2004) relatam que o contexto de saída daqueles de seus países de origem afeta diretamente as oportunidades no país de destino. Hass (2011) esclarece que a política migratória dos países busca exercer o papel de controle dos fluxos migratórios, seja por meio da exigência de vistos, de repressão política ou até mesmo por migração estimulada pelo próprio país ao convidar trabalhadores para se instalarem nele. Esse tipo de migração também pode ser percebido como uma maneira de formalizar fluxos migratórios já existentes.

Outro aspecto mencionado por Haas (2011) é a importância das redes migratórias. $O$ autor argumenta que elas facilitam o fluxo migratório contínuo burlando, ativamente, a tentativa dos Estados de controlar a migração como, por exemplo, ao facilitar a entrada de imigrantes indocumentados em diversos países até que consigam se estabelecer no país de destino final. Além das barreiras iniciais presentes no fluxo migratório, Peroni, Riilo e Sarracino (2016) relatam que, ao chegar ao país de destino, imigrantes também enfrentam diversas barreiras para se colocarem no mercado de trabalho formal, tais como falta de proficiência na língua e de adaptação cultural, problemas de ordem migratória que, de acordo com a legislação do país de destino, podem colocar os imigrantes em situação irregular ou ilegal. Diante dessas barreiras, muitos deles encontram no empreendedorismo uma forma de autossustento e de se inserirem social e economicamente na nova sociedade em que se propuseram a viver (Diniz et al., 2019).

A vulnerabilidade que imigrantes e refugiados vivenciam - especialmente aqueles que migraram em contextos precários como os de guerra e de catástrofes naturais - gera sentimento de solidariedade entre coétnicos e entre a população local em que estes se encontram inseridos. Esse sentimento de solidariedade acaba se constituindo uma importante fonte de diversos recursos que contribuem para a atividade empreendedora dos imigrantes (Zhou, 2004; Diniz et al., 2019).

\subsection{Redes Sociais e Capital Social}

Pesquisadores como Burt (2001), Coleman (1988), Correa e Vale (2017), Correa, Vale e Pinto (2018), Granovetter (1973; 1985; 1988; 2005b; 2008), Sandberg, Immonen e Kok (2019) e Uzzi (1977) têm verificado, em suas pesquisas empíricas, que a estrutura das redes sociais de um indivíduo está relacionada de forma direta à sua capacidade de identificar oportunidades, como um emprego ou um negócio. Nesse sentido, Granovetter (1973) analisa o comportamento de indivíduos pertencentes a redes sociais a fim de averiguar como estas moldam ou restringem o comportamento e como indivíduos manipulam tais redes para alcançar seus objetivos. De acordo com o autor, as redes são compostas por dois tipos de laços denominados fracos e fortes. Os laços fortes são aqueles compostos por contatos frequentes e duradouros que geram redes coesas, solidariedade e confiança, encontrados, normalmente, entre familiares e amigos de maior proximidade. Esse tipo de rede tem grande poder de sanção, seja formal ou informal, o que pode comprometer a reputação e até promover a exclusão dos indivíduos da comunidade.

Além disso, pode aprisionar os indivíduos em determinado tipo de estrutura (rede). Portanto, os indivíduos encontram dificuldades para inserir novos membros à sua rede de contatos e as informações que circulam dentro de redes compostas, em sua 
maioria, por laços fortes, são consideradas redundantes e pouco relevantes. Os laços fracos, por sua vez, são aqueles pouco frequentes, mas que são relevantes na disponibilização de diversos tipos de recursos e de informações valiosas.

Na visão de Correa e Vale (2017) e Correa et al. (2018), os indivíduos com poucos laços fracos são privados de informações de partes distantes do sistema social e ficam restritos às notícias do ambiente local e às de amigos próximos. Assim, aqueles sistemas sociais muito fechados, que não possuem laços fracos, serão fragmentados e terão pouco acesso a ideias novas e não redundantes.

Granovetter (1973) ainda esclarece que as redes sociais dos indivíduos podem apresentar diferentes densidades, podendo ser classificadas como redes densas e redes estendidas ou menos densas. As redes densas são formadas, em sua maioria, por laços fortes e apresentam maior coesão e alto nível de solidariedade e de confiança. Já as redes estendidas ou menos densas são aquelas formadas comumente por laços fracos. Nesse tipo de rede, verifica-se grande volume de informações relevantes e acesso a diversos tipos de recursos que podem auxiliar a atividade empreendedora.

Diante disso, um importante fator deve ser levando em consideração: o capital social. Coleman (1988) define o capital social como sendo os recursos disponíveis nas estruturas sociais das quais o indivíduo faz parte. Segundo o autor, o capital social é uma variedade de diferentes entidades com dois elementos em comum: aspectos da estrutura social e facilitadores de certas ações dos atores dentro da estrutura. Assim como outras formas de capital, o autor entende que o capital social é produtivo, tornando possível o alcance de certos fins que, na sua ausência, não seriam possíveis de se alcançar.

Para Coleman (1988), as relações sociais - ou redes de contato - constituem recursos de capital úteis para os indivíduos. Uma das formas de capital social citadas pelo autor é o canal de informações. A informação é o alicerce para a ação. De acordo com Correa et al. (2018) e Sandberg et al. (2019), uma das maneiras de se adquirir informações relevantes consiste em usar as relações sociais que são mantidas especialmente entre os laços fracos, ou seja, uma simples conversa entre conhecidos pode fornecer informações importantes sobre oportunidades de investimentos e de negócios, entre outros.
Diferentemente para Bourdieu (2002), o capital social é um bem individual. $O$ autor aborda os benefícios obtidos pelos indivíduos mediante sua participação em grupos ou em redes sociais. Os dois elementos que constituem o capital social, para o autor, são as redes de relações sociais - que permitem aos indivíduos ter acesso aos recursos dos membros dos grupos ou das redes - e a quantidade e a qualidade de recursos dos grupos. Um aspecto importante do capital social destacado por Bourdieu (2002) são os ganhos obtidos pelos indivíduos em decorrência de sua participação nos grupos. É essa participação que thes permite apropriar-se dos benefícios materiais e simbólicos que circulam entre os membros das redes (Correa \& Vale, 2017; Correa et al., 2018; Diniz et al., 2019).

Segundo essa perspectiva, indivíduos inseridos em uma grande rede cujos integrantes possuem recursos econômicos ou humanos teriam mais facilidade de encontrar oportunidades de um novo emprego ou negócio. Burt (2001) discorre sobre a importância de duas estruturas de rede que criam capital social: as redes fechadas (ou enclausuradas) e os "buracos estruturais". Para o autor, a primeira poderia gerar valor (capital social) por meio de elementos (atores) interconectados e a segunda por meio da "intermediação" (brokers) entre redes pouco conectadas.

Burt (2001) ressalta que as conexões entre os indivíduos em uma estrutura de rede podem ser bem diferentes umas das outras. Sendo assim, quem está melhor conectado ou mesmo possui uma boa conexão pode obter melhores vantagens de sua posição em relação à rede.

Nesse contexto, podemos ressaltar a importância da questão do embeddedness (imersão) abordada por Granovetter (1985; 2008). O autor considera que é no interior das estruturas sociais baseadas em redes interpessoais que são geradas condições para o desenvolvimento de empreendimentos, na medida em que é a interação entre os indivíduos que possibilita a estrutura e o acesso ao capital social, sendo a ação humana afetada pelas relações sociais em que os atores se encontram imersos (Mizruchi, 2009). Da mesma forma, Wasserman e Faust (1999) defendem que as redes sociais são canais de transferência de recursos, sejam materiais ou imateriais, capazes de disponibilizar a seus membros o acesso a tais recursos de forma diferenciada. 
Percebe-se, então, que a estrutura social configura um tipo de capital que pode gerar, para certos indivíduos ou grupos, vantagem competitiva na busca de seus fins, uma vez que pessoas conectadas alcançam retornos mais altos (Burt, 2001). Enfim, os achados teóricos sobre as relações sociais convergem para uma sobreposição quanto ao papel dos atores. A ideia é que as redes de relações enraizadas (imersas), seja de laço forte ou de laço fraco, podem trazer benefícios para os indivíduos, representando um importante recurso para a atividade empreendedora.

\subsection{Modelo Teórico para Análise dos Dados}

A discussão sobre empreendedorismo de refugiados, redes sociais e capital social possibilitounos a criação de um modelo teórico para auxiliar na análise dos dados conforme explanação a seguir.
O modelo da Figura 1 busca representar como as redes sociais influenciam o processo empreendedor de refugiados. Conforme mencionado por Shinnar e Zamantili (2019), várias motivações levam os imigrantes ao empreendedorismo, sendo a oportunidade e a necessidade as principais. No entanto, para que o processo empreendedor seja possivel, os indivíduos precisam estar inseridos em determinada estrutura social. De acordo com Coleman (1988), Burt (2001) e Diniz et al. (2019), pode-se entender como estruturas sociais as relações existentes entre os indivíduos.

Granovetter $(1985 ;$ 2008) considera que é no interior das estruturas sociais baseadas em redes interpessoais que são construídos empreendimentos e que emergem as instituições, ou seja, a interação entre os indivíduos é que gera a estrutura (rede), sendo a ação humana afetada pelas relações sociais em que os atores se encontram imersos (Mizruchi, 2009).

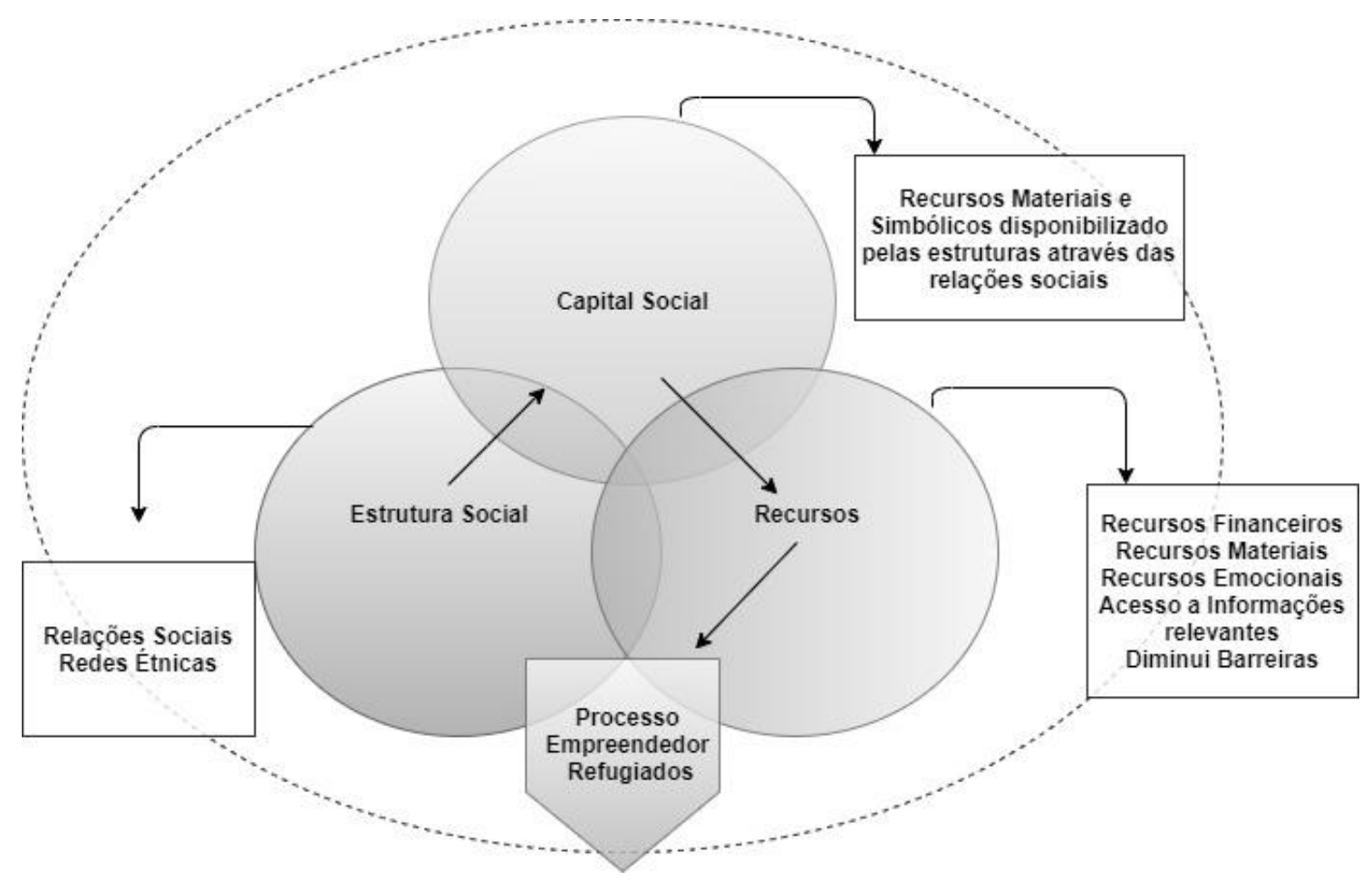

Figura 1 - Influência das Redes Sociais no Processo Empreendedor de Refugiados Fonte: Elaborado pelos autores

Em consonância com a literatura, o modelo teórico apresenta a estrutura social como fonte de capital social. Conforme abordado por Coleman (1988), Correa e Vale (2017), Correa et al. (2018), Diniz et al. (2019) e Sandberg et al. (2019), as relações sociais (ou redes de contato) constituem-se como fonte de recursos úteis para os indivíduos. Bourdieu (2002) acrescenta, mencionando os ganhos e os benefícios obtidos pelos indivíduos mediante sua participação em grupos ou em redes sociais. Nesse contexto, estão inseridas as redes étnicas. 
Aldrich e Waldigner (1990), Portes e Zhou (1992) e Zhou (2004) relatam que os indivíduos imersos em estruturas compostas por coétnicos favorecem o empreendedorismo étnico, haja vista que a falta de recursos e a falta de proficiência no idioma fazem com que os membros dessa estrutura se mobilizem oferecendo ajuda mútua visando a adaptação, a diminuição das barreiras no país de destino e o acesso a recursos e estratégias de gestão que facilitam o processo empreendedor. Isso gera solidariedade limitada, o que favorece o acesso a recursos e a criação de normas de comportamento entre os coétnicos que estejam enfrentando situações adversas no país de destino.

No modelo teórico, também são abordados os aspectos relativos ao capital social mencionados por Bourdieu (2002), Burt (2001), Coleman (1998) e Sandberg et al. (2019), em que o capital social é capturado a partir da estrutura social, ou seja, ele está imerso na estrutura. Para Bourdieu (2002), cada membro da estrutura é detentor de capital social, sendo que a interação do indivíduo com os demais membros é que lhes permite apropriar-se dos benefícios materiais e simbólicos que circulam entre os atores da rede. Segundo essa teoria, indivíduos inseridos em uma grande rede cujos integrantes possuam recursos - econômicos ou humanos - teriam mais facilidade de encontrar oportunidades de um novo emprego ou de criar um novo negócio.

Coleman (1998) e Correa e Vale (2017) ainda ressaltam que uma das formas de capital social é o canal de informações, e este pode ser considerado como o alicerce para a ação. Uma das maneiras de se adquirir informações relevantes consiste em usar as relações sociais, pois elas podem fornecer dados importantes sobre oportunidades de investimentos e de negócios, entre outros. Correa et al. (2018) e Sandberg et al. (2019) também esclarecem que por meio do capital social podem-se acessar variados tipos de recursos, como capital físico, capital humano e capital financeiro e estes, por conseguinte, contribuem para o processo empreendedor.

Burt (2001) e Diniz et al. (2019) complementam afirmando que as pessoas que estão em melhor posição em uma estrutura social são aquelas mais conectadas, uma vez que obtêm maiores vantagens competitivas em relação aos diversos e diferentes atores das redes. Os atributos de algumas pessoas como o fato de serem mais inteligentes, atraentes, articuladas, habilidosas - podem ser uma vantagem competitiva na estrutura da rede, compondo seu capital social. Os autores concluem que quem está melhor conectado ou mesmo quem possui uma boa conexão pode obter melhores vantagens de sua posição relativa na rede por meio do acesso ao capital social e, consequentemente, aos recursos por ele disponibilizado.

Em síntese, a literatura nos apresenta elementos que suportam o modelo teórico apresentado, em que o processo empreendedor de refugiados abarca todos os aspectos concernentes às relações sociais (redes), sejam elas étnicas ou não étnicas. Dessa forma, acredita-se que o processo empreendedor de refugiados é diretamente afetado pelas estruturas sociais e que estas são elementos-chave para a criação de novos negócios, haja vista que é por meio delas que se pode ativar o capital social e acessar os recursos necessários que irão facilitar o processo empreendedor dos imigrantes.

\section{Metodologia}

A pesquisa realizada foi de natureza qualitativa e o método adotado foi o estudo de caso múltiplos. De acordo com Yin (2005), a essência de um estudo de caso é esclarecer uma decisão ou um conjunto de decisões, bem como o motivo pelo qual elas foram tomadas, como foram implementadas e quais foram os resultados alcançados. A principal estratégia de coleta de dados foi o uso de entrevistas semiestruturadas e realizadas presencialmente com 14 refugiados sírios, comerciantes ou empreendedores estabelecidos no Rio de Janeiro, e com 10 refugiados sírios estabelecidos na cidade de Belo Horizonte e região metropolitana, os quais constituíram os 24 casos analisados. Os pesquisadores seguiram um roteiro semiestruturado (Creswell \& Clark, 2017; Denzin \& Lincoln, 2011) que continha questões sociodemográficas e de negócios. $O$ roteiro da entrevista incluiu o levantamento de dados sociodemográficos e profissionais dos empreendedores, informações sobre a decisão de imigrarem para o Brasil e como se deu sua chegada e a criação de seus negócios. As entrevistas foram realizadas na rua, nos estabelecimentos dos empreendedores e em um festival de comida e de cultura sírio-libanesa organizado pelo consulado sírio em Belo Horizonte.

Anotações e observações de campo complementaram a coleta de dados. Cada entrevista 
durou de 40 a 60 minutos, com gravações feitas usando um celular smartphone sendo, depois, transcritas integralmente. Seu objetivo foi o de compreender as trajetórias dos entrevistados e o processo de criação de seus negócios. Isso permitiu aos pesquisadores conhecerem suas histórias ao chegarem ao Brasil e a existência ou não de uma conexão com redes de apoio.

Os dados também foram triangulados com fontes documentais da mídia e com a literatura existente sobre empreendedorismo imigrante e enclaves éticos. As entrevistas foram realizadas entre agosto de 2017 e maio de 2019, sendo algumas em português e outras em inglês com auxílio do Google tradutor, aplicativo instalado no celular do entrevistador. Os pesquisadores seguiram os procedimentos de Eisenhardt (1989) ao apresentarem os casos e analisarem os dados coletados, visando fazer proposições. A Tabela 1 mostra a informação geral dos entrevistados selecionados para o estudo de casos e para a análise.

Tabela 1 - Informações dos Entrevistados

\begin{tabular}{|c|c|c|c|c|c|c|c|c|}
\hline Imigrante & Idade & Atividade & Moradia & $\begin{array}{l}\text { Local de } \\
\text { Trabalho }\end{array}$ & Cidade & Sexo & $\begin{array}{l}\text { Tempo no } \\
\text { Brasil }\end{array}$ & $\begin{array}{l}\text { Experiência } \\
\text { anterior ou } \\
\text { formação }\end{array}$ \\
\hline Braheem & $\begin{array}{l}32 \\
\text { anos }\end{array}$ & $\begin{array}{l}\text { Quiosque de } \\
\text { salgados } \\
\text { árabes }\end{array}$ & $\begin{array}{lr}\text { Centro } & \text { de } \\
\text { Niterói } & \text { com } \\
\text { primo } & \\
\end{array}$ & $\begin{array}{l}\text { Quiosque no } \\
\text { Niterói } \\
\text { Shopping }\end{array}$ & Niterói & $M$ & 9 meses & $\begin{array}{l}\text { Engenheiro } \\
\text { mecânico na } \\
\text { Síria }\end{array}$ \\
\hline Ali & $\begin{array}{l}22 \\
\text { anos }\end{array}$ & $\begin{array}{l}\text { Quiosque de } \\
\text { salgados } \\
\text { árabes }\end{array}$ & $\begin{array}{l}\text { Tijuca com } \\
\text { tios }\end{array}$ & $\begin{array}{l}\text { Estação } \\
\text { Carioca }\end{array}$ & $\begin{array}{l}\text { Rio de } \\
\text { Janeiro }\end{array}$ & $M$ & $\begin{array}{l}1 \text { ano e } 4 \\
\text { meses }\end{array}$ & $\begin{array}{l}\text { Trabalhava } \\
\text { com comida } \\
\text { na Síria }\end{array}$ \\
\hline Ihab & $\begin{array}{l}26 \\
\text { anos }\end{array}$ & $\begin{array}{l}\text { Quiosque de } \\
\text { salgados } \\
\text { árabes }\end{array}$ & $\begin{array}{l}\text { Tomás } \\
\text { Coelho com } \\
\text { dois amigos }\end{array}$ & $\begin{array}{l}\text { Estação } \\
\text { Cinelândia }\end{array}$ & $\begin{array}{l}\text { Rio de } \\
\text { Janeiro }\end{array}$ & M & 4 meses & $\begin{array}{l}\text { Não } \\
\text { informado }\end{array}$ \\
\hline Ousama & $\begin{array}{l}23 \\
\text { anos }\end{array}$ & $\begin{array}{l}\text { Quiosque de } \\
\text { salgados } \\
\text { árabes }\end{array}$ & $\begin{array}{l}\text { Cosme Velho } \\
\text { com pai e } \\
\text { irmãos }\end{array}$ & Praça XV & $\begin{array}{l}\text { Rio de } \\
\text { Janeiro }\end{array}$ & $M$ & 3 anos & $\begin{array}{l}\text { Faculdade na } \\
\text { Síria }\end{array}$ \\
\hline Omran & $\begin{array}{l}23 \\
\text { anos }\end{array}$ & $\begin{array}{l}\text { Quiosque de } \\
\text { salgados } \\
\text { árabes }\end{array}$ & $\begin{array}{l}\text { Cosme Velho } \\
\text { com pai e } \\
\text { irmãos }\end{array}$ & Praça XV & $\begin{array}{l}\text { Rio de } \\
\text { Janeiro }\end{array}$ & M & $\begin{array}{l}2 \text { anos e } 5 \\
\text { meses }\end{array}$ & $\begin{array}{l}\text { Trabalhava } \\
\text { com ferro na } \\
\text { Síria }\end{array}$ \\
\hline Armin & $\begin{array}{l}27 \\
\text { anos }\end{array}$ & $\begin{array}{l}\text { Quiosque de } \\
\text { salgados } \\
\text { árabes }\end{array}$ & $\begin{array}{l}\text { Lapa com } \\
\text { pai, mãe e } \\
\text { irmãos }\end{array}$ & $\begin{array}{l}\text { Em frente ao } \\
\text { Botafogo Praia } \\
\text { Shopping }\end{array}$ & $\begin{array}{l}\text { Rio de } \\
\text { Janeiro }\end{array}$ & M & 4 anos & $\begin{array}{l}\text { Trabalhava } \\
\text { com turismo } \\
\text { na Síria }\end{array}$ \\
\hline $\begin{array}{l}\text { Não } \\
\text { Identificado }\end{array}$ & $\begin{array}{l}22 \\
\text { anos }\end{array}$ & $\begin{array}{l}\text { Quiosque de } \\
\text { salgados } \\
\text { árabes }\end{array}$ & $\begin{array}{l}\text { Andaraí com } \\
\text { amigos }\end{array}$ & $\begin{array}{l}\text { Rua Mena } \\
\text { Barreto, } \\
\text { Botafogo }\end{array}$ & $\begin{array}{l}\text { Rio de } \\
\text { Janeiro }\end{array}$ & $M$ & 9 meses & $\begin{array}{l}\text { Cursava } \\
\text { faculdade de } \\
\text { Matemática } \\
\text { na Síria } \\
\end{array}$ \\
\hline Abdullah & $\begin{array}{l}27 \\
\text { anos }\end{array}$ & $\begin{array}{l}\text { Quiosque de } \\
\text { salgados } \\
\text { árabes }\end{array}$ & $\begin{array}{l}\text { Paróquia São } \\
\text { João Batista, } \\
\text { Botafogo } \\
\text { com irmão }\end{array}$ & $\begin{array}{l}\text { Rua Mena } \\
\text { Barreto, } \\
\text { Botafogo }\end{array}$ & $\begin{array}{l}\text { Rio de } \\
\text { Janeiro }\end{array}$ & $M$ & $\begin{array}{l}2 \text { anos e } 6 \\
\text { meses }\end{array}$ & $\begin{array}{l}\text { Formado em } \\
\text { Letras } \\
\text { Árabe-Inglês, } \\
\text { tinha } \\
\text { lanchonetes } \\
\text { na Síria }\end{array}$ \\
\hline Nour & $\begin{array}{l}25 \\
\text { anos }\end{array}$ & $\begin{array}{l}\text { Quiosque de } \\
\text { salgados } \\
\text { árabes }\end{array}$ & $\begin{array}{l}\text { Paróquia São } \\
\text { João Batista, } \\
\text { Botafogo } \\
\text { com marido } \\
\text { e três filhos }\end{array}$ & $\begin{array}{l}\text { Ao lado da } \\
\text { Paróquia }\end{array}$ & $\begin{array}{l}\text { Rio de } \\
\text { Janeiro }\end{array}$ & $\mathrm{F}$ & $\begin{array}{l}\text { Não } \\
\text { informado }\end{array}$ & $\begin{array}{l}\text { Trabalhava } \\
\text { com } \\
\text { depilação a } \\
\text { laser na Síria }\end{array}$ \\
\hline Mouhamad & $\begin{array}{l}32 \\
\text { anos }\end{array}$ & $\begin{array}{l}\text { Quiosque de } \\
\text { salgados } \\
\text { árabes }\end{array}$ & $\begin{array}{l}\text { Paróquia São } \\
\text { João Batista, } \\
\text { Botafogo } \\
\text { com marido } \\
\text { e três filhos }\end{array}$ & $\begin{array}{l}\text { Ao lado da } \\
\text { Paróquia }\end{array}$ & $\begin{array}{l}\text { Rio de } \\
\text { Janeiro }\end{array}$ & $M$ & $\begin{array}{l}\text { Não } \\
\text { informado }\end{array}$ & $\begin{array}{l}\text { Trabalhava } \\
\text { em } \\
\text { restaurante } \\
\text { e depois } \\
\text { como diretor } \\
\text { de vendas na } \\
\text { Síria }\end{array}$ \\
\hline
\end{tabular}




\begin{tabular}{|c|c|c|c|c|c|c|c|c|}
\hline Imigrante & Idade & Atividade & Moradia & $\begin{array}{l}\text { Local de } \\
\text { Trabalho }\end{array}$ & Cidade & Sexo & $\begin{array}{l}\text { Tempo no } \\
\text { Brasil }\end{array}$ & $\begin{array}{l}\text { Experiência } \\
\text { anterior ou } \\
\text { formação }\end{array}$ \\
\hline Maias & $\begin{array}{l}25 \\
\text { anos }\end{array}$ & $\begin{array}{l}\text { Quiosque de } \\
\text { salgados } \\
\text { árabes }\end{array}$ & $\begin{array}{l}\text { Mora } \\
\text { sozinho no } \\
\text { Cantagalo }\end{array}$ & $\begin{array}{l}\text { Av. Nossa Sra. } \\
\text { Copacabana }\end{array}$ & $\begin{array}{l}\text { Rio de } \\
\text { Janeiro }\end{array}$ & M & $\begin{array}{l}\text { Não } \\
\text { informado }\end{array}$ & $\begin{array}{l}\text { Engenheiro e } \\
\text { tinha loja na } \\
\text { Síria }\end{array}$ \\
\hline Ali & $\begin{array}{l}29 \\
\text { anos }\end{array}$ & $\begin{array}{l}\text { Quiosque de } \\
\text { salgados } \\
\text { árabes }\end{array}$ & $\begin{array}{l}\text { Mora } \\
\text { sozinho em } \\
\text { Copacabana }\end{array}$ & $\begin{array}{l}\text { Av. Nossa Sra. } \\
\text { Copacabana }\end{array}$ & $\begin{array}{l}\text { Rio de } \\
\text { Janeiro }\end{array}$ & $M$ & $\begin{array}{l}\text { Não } \\
\text { informado }\end{array}$ & $\begin{array}{l}\text { Não } \\
\text { informado }\end{array}$ \\
\hline Mohammad & $\begin{array}{l}21 \\
\text { anos }\end{array}$ & $\begin{array}{l}\text { Quiosque de } \\
\text { salgados } \\
\text { árabes }\end{array}$ & $\begin{array}{l}\text { Mora na } \\
\text { Tijuca com o } \\
\text { tio }\end{array}$ & $\begin{array}{l}\text { Av. Nossa Sra. } \\
\text { Copacabana }\end{array}$ & $\begin{array}{l}\text { Rio de } \\
\text { Janeiro }\end{array}$ & M & $\begin{array}{l}\text { Não } \\
\text { informado }\end{array}$ & $\begin{array}{l}\text { Fazia } \\
\text { faculdade de } \\
\text { Árabe }\end{array}$ \\
\hline Monzer & $\begin{array}{l}46 \\
\text { anos }\end{array}$ & $\begin{array}{l}\text { Quiosque de } \\
\text { salgados } \\
\text { árabes }\end{array}$ & $\begin{array}{l}\text { Mora na } \\
\text { Lapa com tia, } \\
\text { primo e filho }\end{array}$ & $\begin{array}{l}\text { Largo do } \\
\text { Machado }\end{array}$ & $\begin{array}{l}\text { Rio de } \\
\text { Janeiro }\end{array}$ & M & 10 meses & \begin{tabular}{lr}
\multicolumn{2}{l}{ Trabalhou } \\
com várias \\
coisas na \\
Síria
\end{tabular} \\
\hline Foad & $\begin{array}{l}36 \\
\text { anos }\end{array}$ & $\begin{array}{l}\text { Restaurante } \\
\text { de comida } \\
\text { árabe }\end{array}$ & $\begin{array}{l}\begin{array}{l}\text { Esposa } \\
\text { filhos em } \\
\text { Betim/MG }\end{array} \\
\end{array}$ & $\begin{array}{l}\text { Rua Rio de } \\
\text { Janeiro } \\
\text { Centro, Betim }\end{array}$ & Betim & M & 05 anos & $\begin{array}{ll}\text { Chefe } & \text { de } \\
\text { cozinha } & \text { na } \\
\text { Síria } & \end{array}$ \\
\hline Yazan & $\begin{array}{l}25 \\
\text { anos }\end{array}$ & $\begin{array}{l}\text { Lanchonete } \\
\text { árabe }\end{array}$ & $\begin{array}{lr}\text { Mora } & \text { com } \\
\text { irmão } & \text { em } \\
\text { BH/MG } & \\
\end{array}$ & $\begin{array}{l}\text { Alameda Oscar } \\
\text { Niemayer }\end{array}$ & $\begin{array}{l}\text { Nova } \\
\text { Lima }\end{array}$ & M & 05 anos & $\begin{array}{l}\text { Garçom na } \\
\text { Síria }\end{array}$ \\
\hline Nizar & $\begin{array}{l}34 \\
\text { anos }\end{array}$ & $\begin{array}{l}\text { Salão de } \\
\text { Beleza }\end{array}$ & $\begin{array}{lr}\text { Mora } & \text { com } \\
\text { esposa } & \text { e } \\
\text { irmão } & \text { em } \\
\text { BH/MG } & \\
\end{array}$ & $\begin{array}{l}\text { Rua } \\
\text { Pernambuco } \\
\text { Savassi }\end{array}$ & $\mathrm{BH}$ & M & 05 anos & $\begin{array}{ll}\text { Salão } & \text { de } \\
\text { beleza } & \text { na } \\
\text { Síria } & \end{array}$ \\
\hline Elian Sokkar & $\begin{array}{l}30 \\
\text { anos }\end{array}$ & $\begin{array}{l}\text { Lanchonete } \\
\text { árabe }\end{array}$ & $\begin{array}{lr}\text { Mora } & \text { com } \\
\text { irmão } & \text { e } \\
\text { amigo } & \text { sírio } \\
\text { em BH } & \\
\end{array}$ & $\begin{array}{l}\text { Rua Paraíba } \\
\text { Savassi }\end{array}$ & $\mathrm{BH}$ & M & 05 anos & $\begin{array}{l}\text { Joalheiro na } \\
\text { Síria }\end{array}$ \\
\hline $\begin{array}{l}\text { John } \\
\text { Eshak }\end{array}$ & $\begin{array}{l}23 \\
\text { anos }\end{array}$ & $\begin{array}{l}\text { Lanchonete } \\
\text { árabe }\end{array}$ & $\begin{array}{ll}\text { Mora } & \text { com } \\
\text { amigo } & \text { sírio } \\
\text { em BH } & \\
\end{array}$ & $\begin{array}{l}\text { Av. Getúlio } \\
\text { Vargas Savassi }\end{array}$ & $\mathrm{BH}$ & M & 05 anos & $\begin{array}{l}\text { Estudante de } \\
\text { Medicina na } \\
\text { Síria }\end{array}$ \\
\hline $\begin{array}{l}\text { Khaled } \\
\text { Tomeh }\end{array}$ & $\begin{array}{l}34 \\
\text { anos }\end{array}$ & $\begin{array}{l}\text { Lanchonete } \\
\text { árabe }\end{array}$ & $\begin{array}{l}\text { Mora com } \\
\text { esposa, filha } \\
\text { e pais em } \mathrm{BH}\end{array}$ & $\begin{array}{l}\text { Rua } \\
\text { Goitacazes } \\
\text { Centro } \\
\end{array}$ & $\mathrm{BH}$ & M & 05 anos & $\begin{array}{l}\text { Engenheiro } \\
\text { de alimentos } \\
\text { na Síria }\end{array}$ \\
\hline Zack & $\begin{array}{l}25 \\
\text { anos }\end{array}$ & $\begin{array}{l}\text { Quiosque de } \\
\text { salgados } \\
\text { árabes }\end{array}$ & $\begin{array}{l}\text { Mora com os } \\
\text { pais em } \mathrm{BH}\end{array}$ & $\begin{array}{l}\text { Feira do } \\
\text { Mineirinho }\end{array}$ & $\mathrm{BH}$ & $\mathrm{M}$ & 04 anos & $\begin{array}{l}\text { Barbeiro na } \\
\text { Síria }\end{array}$ \\
\hline Gaby & $\begin{array}{l}29 \\
\text { anos }\end{array}$ & $\begin{array}{l}\text { Lanchonete } \\
\text { árabe }\end{array}$ & $\begin{array}{l}\text { Mora com a } \\
\text { família em } \\
\mathrm{BH}\end{array}$ & $\begin{array}{l}\text { Av. Francisco } \\
\text { Sá - Prado }\end{array}$ & $\mathrm{BH}$ & M & 09 anos & $\begin{array}{l}\text { Estudante de } \\
\text { Economia na } \\
\text { Síria }\end{array}$ \\
\hline Nabil & $\begin{array}{l}41 \\
\text { anos }\end{array}$ & $\begin{array}{l}\text { Quiosque de } \\
\text { salgados } \\
\text { árabes }\end{array}$ & $\begin{array}{l}\text { Mora com a } \\
\text { família em } \\
\mathrm{BH}\end{array}$ & $\begin{array}{l}\text { Feira do } \\
\text { Mineirinho }\end{array}$ & $\mathrm{BH}$ & M & 04 anos & $\begin{array}{l}\text { Dono de } \\
\text { restaurante } \\
\text { na Síria }\end{array}$ \\
\hline Farahad & $\begin{array}{l}32 \\
\text { anos }\end{array}$ & $\begin{array}{l}\text { Quiosque de } \\
\text { salgados } \\
\text { árabes }\end{array}$ & $\begin{array}{l}\text { Mora com a } \\
\text { família em } \\
\text { Betim }\end{array}$ & $\begin{array}{l}\text { Em frente à } \\
\text { Igreja Batista } \\
\text { da Lagoinha - } \\
\text { Betim }\end{array}$ & $\mathrm{BH}$ & M & 02 anos & $\begin{array}{l}\text { Pintor } \\
\text { carro }\end{array}$ \\
\hline
\end{tabular}

Fonte: Dados coletados pelos autores

A maioria dos entrevistados foi do sexo masculino, com jovens e solteiros fugindo da guerra e buscando juntar dinheiro para, posteriormente, retornarem a seu país de origem. Os entrevistados trabalham com barracas de salgados, lanchonetes e restaurantes, pois segundo eles, é algo que não exige o domínio do português, além de que, geralmente, sabem cozinhar ou contam com o apoio de familiares na produção dos alimentos e/ou têm acesso aos salgados nas fábricas onde são produzidos.

Para a identificação e o acesso aos entrevistados no Rio de Janeiro, buscou-se estabelecer um contato direto com eles em seus locais de estabelecimento em geral, estão estabelecidos em ruas de grande movimento na Zona Sul e no centro da cidade. Além dos 14 entrevistados sírios que efetivamente 
aceitaram fazer parte da pesquisa, havia outros quatro que se recusaram. Já no caso dos entrevistados de Belo Horizonte, o acesso aos entrevistados deu-se por meio da participação de um festival de comida e de cultura sírio-libanesa promovido pelo consulado sírio em Belo Horizonte.

O método de análise das entrevistas seguiu o protocolo de Bardin (2006), sendo aquela dividida em três fases: (i) pré-análise; (ii) exploração do material; (iii) tratamento dos resultados, inferência e interpretação. Durante a fase da pré-análise, realizou-se a transcrição integral das entrevistas, organizando-as com o objetivo de torná-las operacionalizáveis, sistematizando-se as ideias iniciais. Nesse processo de organização, foram realizadas quatro etapas, sendo elas: i) leitura flutuante, em que se deu um primeiro contato com os textos transcritos, derivados da coleta de dados por meio de entrevistas; ii) escolha dos documentos ou de trechos deles, realizando-se uma demarcação do que seria analisado; iii) formulação de hipóteses prévias derivadas das entrevistas e iv) referenciação dos índices e elaboração de indicadores por meio de recortes de passagens dos textos analisados (Bardin, 2006).

A segunda fase consistiu na exploração do material e sua categorização. Seguindo as recomendações de Gioia, Corley e Hamilton (2013), em que são elencados os conceitos de primeira e de segunda ordem e as dimensões agregadas, apresenta-se, na Figura 2, o processo de codificação em três etapas.

Figura 2 - Processo de Codificação em Três Etapas

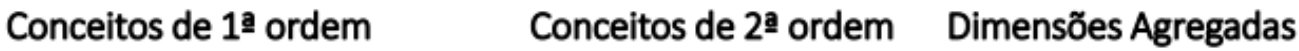

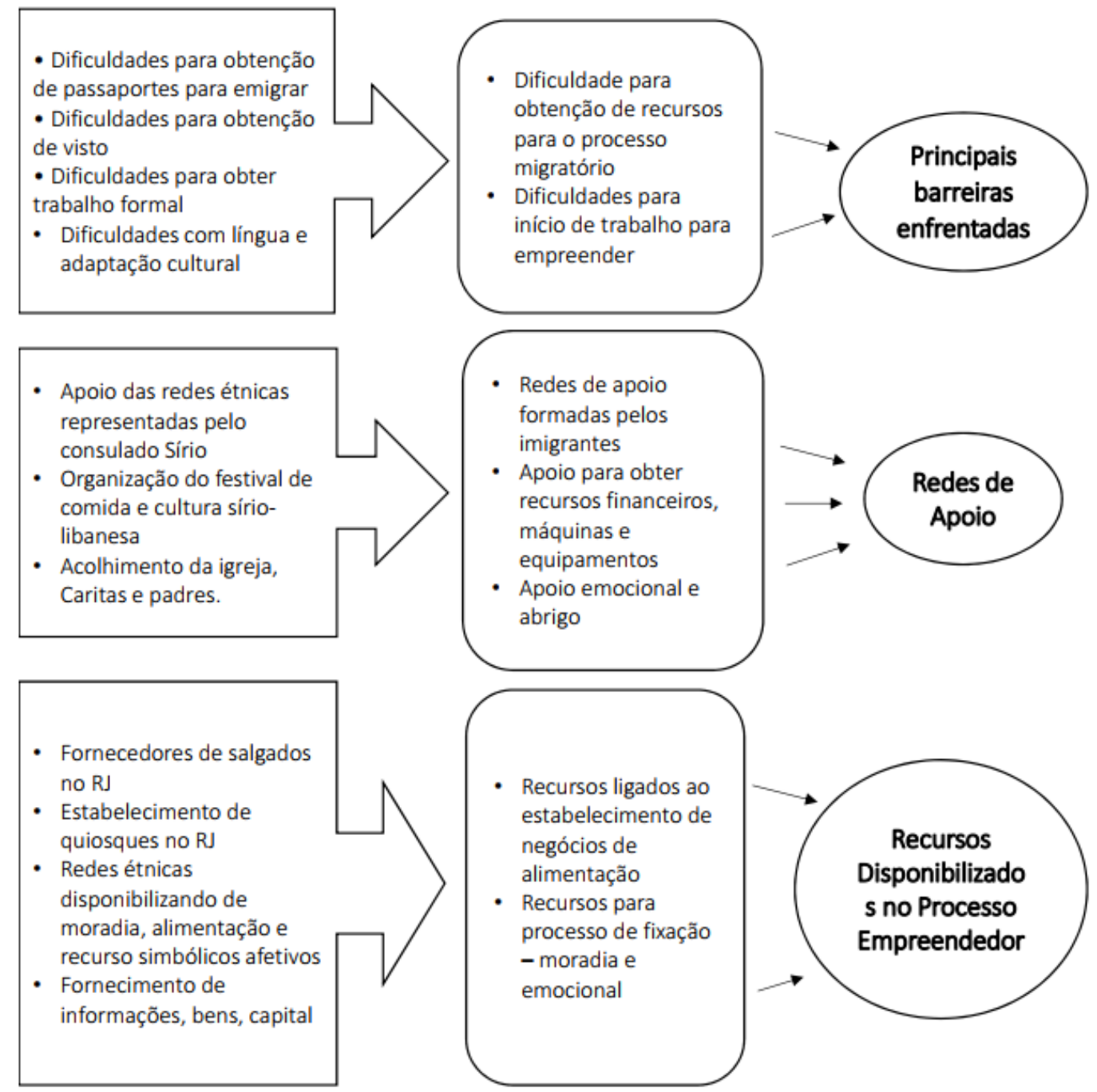

Fonte: Elaborado pelos autores 
As dimensões agregadas que nomeiam as categorias foram: barreiras enfrentadas pelos entrevistados, identificação da atuação das redes sociais e recursos disponibilizados no processo empreendedor. A exploração do material nos possibilitou riqueza de interpretações e de inferências sobre o tema tratado (Bardin, 2006). Já durante a terceira fase, de inferência e de interpretação, deu-se o tratamento dos resultados a partir de uma análise reflexiva e crítica acerca dos relatos das entrevistas (Bardin, 2006). Para a análise dos dados, adotou-se o software Atlas.ti, que permitiu a organização das categorias que emergiram da análise para serem confrontadas com o referencial teórico abordado. Por sua natureza qualitativa e exploratória, o objetivo do estudo não foi o de quantificar com precisão o número de empreendedores sírios ou comerciantes, tampouco o de buscar por explicações totalizantes ou generalizações. Conforme anteriormente mencionado, o objetivo foi o de analisar como redes étnicas apoiam e influenciam na criação de novos negócios.

\section{Análise dos Dados}

Após a fase de categorização e de codificação, buscou-se analisar os dados levantados com o propósito de cumprir o objetivo da pesquisa. A análise foi realizada tendo como base o referencial apresentado e o modelo teórico elaborado. Para apresentação dos principais achados derivados das entrevistas em profundidade, foram agrupados os temas comuns que emergiram delas.

No Rio de Janeiro, foram encontradas, pelo menos, duas fábricas de salgados árabes que garantem o sustento de estrangeiros, que os revendem em barracas padronizadas em pontos centrais da cidade. Um desses fornecedores é o sírio Taleb Yázigi, 47, radicado no Brasil há 13 anos, que repassa os salgados para, pelo menos, 20 vendedores que os comercializam em diversos pontos da cidade. A fábrica conta com uma equipe de 16 pessoas, sendo nove refugiados e sete brasileiros, que se

\footnotetext{
2 "A Cáritas é um organismo da Conferência Nacional dos Bispos do Brasil (CNBB). Está organizada em uma rede com 183 entidades-membros, 12 regionais [...] e uma sede nacional. Atua
}

revezam em três turnos para garantir que esfirras, quibes, falafels e biscoitos de gergelim estejam sempre frescos.

A prefeitura do Rio de Janeiro, em 2016, autorizou o trabalho de refugiados como ambulantes, fazendo o negócio das fábricas fornecedoras crescer desde então. Segundo Taleb, a fábrica ajuda, aproximadamente, cem famílias. Os salgados são comercializados por $\mathrm{R} \$ 1$ (um real) a unidade e as caixas com dez salgados pequenos por $\mathrm{R} \$ 5,00$ (cinco reais). Alguns refugiados sírios entrevistados na pesquisa afirmaram que seu lucro gira em torno de $\mathrm{R} \$ 75$ a $\mathrm{R} \$ 100$ por dia.

Além do elo do fornecimento de produtos, há o elo do acolhimento. Tanto no Rio de Janeiro quanto em Belo Horizonte, há padres que falam árabe e promovem, com o apoio da Cáritas Diocesana², abrigos para refugiados em imóveis anexos às igrejas e em apartamentos alugados e mantidos por seus fiéis. Esse trabalho da Cáritas, por sua vez, tem apoio do Acnur (Alto Comissariado da ONU para os Refugiados) e do Comitê Nacional para os Refugiados (Conare), órgão vinculado ao Ministério da Justiça. Em Belo Horizonte e região metropolitana, também foram identificadas igrejas e ONGs evangélicas, tais como a Igreja Batista da Lagoinha e a ONG MAIS (Missão em Apoio à Igreja Sofredora), que recebem, acolhem, ajudam com questões linguísticas e burocráticas e contribuem para o sustento dos refugiados e de imigrantes.

No Rio de Janeiro, Padre Alex, da paróquia de Botafogo, na Zona Sul, relata que "os árabes convivem harmonicamente no mesmo espaço com uma família ucraniana e outra nigeriana. Todos recebem moradia e alimentação pelo período de três meses". Ao retornar da Síria, Padre Alex se prontificou a receber refugiados em sua paróquia com o apoio da Cáritas.

Já em Belo Horizonte, o padre George Rateb Massis, que também é sírio e que vive no Brasil há 18 anos, vem recebendo refugiados desde 2012 graças ao intermédio da Arquidiocese de Belo Horizonte que realiza, há três anos, a campanha "Juntos pela Síria", para angariar fundos para apoio aos refugiados na

em 450 municípios, sendo presença solidária junto às pessoas mais empobrecidas". (http://caritas.org.br/quem-somos-ehistorico) 
capital mineira. Padre George disponibiliza um apartamento na região central de Belo Horizonte que tem capacidade de receber até 18 pessoas. Esse apartamento é mantido com as doações dos fiéis que frequentam a igreja pela qual o Padre George é o responsável. As instalações são simples, mas a convivência entre os refugiados é harmoniosa. Padre George articula uma rede de apoio aos refugiados sírios por meio dos frequentadores da igreja. Cada membro apadrinha um dos refugiados, auxiliando na aquisição da proficiência no idioma, na regularização de documentos, na solicitação de refúgio, em sua inserção no mercado de trabalho, bem como na orientação de diversos assuntos e com apoio emocional.

O consulado sírio em Belo Horizonte também tem se constituído uma importante rede étnica de apoio aos refugiados. Anualmente, organiza um festival de cultura e de comida sírio-libanesa. Nesse evento, os refugiados vendem comidas típicas de sua cultura, facilitando seu empreendedorismo.

\subsection{Principais Barreiras Enfrentadas}

As barreiras enfrentadas pelos refugiados foram diversas, tais como: falta de documentação legal, dificuldades para inserção no mercado formal de trabalho, dificuldades linguísticas, problemas de adaptação cultural e falta de recursos financeiros para o início da atividade empreendedora efetiva, conforme relatam os entrevistados Foad e Yazan:

\footnotetext{
"Meu plano era conseguir os passaportes e ir para Turquia e de lá ir para a Europa. Mas não deu certo, então eu saí para Jordânia. De Damasco fui para Jordânia. [...] Foi mais fácil vir para o Brasil porque os outros países exigiam visto. (Foad)
}

"Passei primeiro pelo Líbano. Morei pouco tempo lá. Meu irmão morava no Líbano, o que é padre [...] Sim, eu tentei, mas realmente não é fácil se conseguir um visto para outros países e o Brasil deu tudo certo para mim, por isso que eu vim." (Yazan)

Nos relatos acima, fica evidente que alguns imigrantes sírios vieram diretamente ao Brasil, enquanto outros realizaram um trajeto passando pela Turquia, pelo Líbano, por Dubai ou pela Jordânia. Em quase todos os relatos coletados, os entrevistados mencionaram que seu destino inicial era a Europa ou os Estados Unidos. Como para esses lugares era necessário que obtivessem vistos, fizeram a opção pelo Brasil pelo fato de não haver tal exigência e por já possuírem contatos no país. Esse achado corrobora com o mencionado por Haas (2011), em que as políticas migratórias - como por exemplo a exigência de vistos - buscam exercer o controle do fluxo migratório; no entanto, as redes migratórias facilitam e podem alterar o destino dos fluxos migratórios iniciais, seja facilitando a entrada ilegal no país, seja funcionando como ponte oferecendo acolhimento e facilitando o acesso a recursos.

Outro fator identificado como barreira foi a permissão para o trabalho formal no país de destino. Tanto na Jordânia como na Turquia e no Líbano, os sírios não tinham permissão para o trabalho formal. A dificuldade com o idioma e com a cultura também foi considerada como uma barreira para os refugiados. Ao chegarem ao Brasil, tiveram dificuldade para se comunicar, pois não falavam o português e, em consequência disso, enfrentaram dificuldades para conseguir emprego e recursos para sua sobrevivência. Os refugiados também relataram dificuldades com o aspecto gastronômico e cultural, como pode ser percebido nos relatos abaixo, dos entrevistados Foad e Yazan.

\begin{abstract}
"Eu sofri muito, foi muito sofrido porque teve a questão da língua, pois, para arrumar um emprego melhor precisava falar a língua e não tinha quem nos ensinasse, foi muito difícil [...] Então eu sofri aqui com tudo. Eu sofri com a questão da língua, alimentos, cultura, todas estas coisas." (Foad)

"Então, eu cheguei aqui no Brasil, um país que eu sempre quis conhecer, mas e a língua? Aí que está, a língua [...] Quando aprendi a língua fui direcionando meu caminho para trabalhar com comida". (Yazan)
\end{abstract}

No entanto, os entrevistados Ali e Abdullah diferem de Foad e Yazan, uma vez que não tiveram dificuldades em se adaptar à cultura brasileira, conforme relatos a seguir:

"Muito diferente, mas cultura é bom, livre, mais livre. Gostei. Gente boa." (Ali)

"Cultura brasileira maravilhosa, misturada, aberta para todo mundo [...] coisa melhor do Brasil é que é misturada." (Abdullah) 
Esses relatos vão ao encontro do que Peroni et al. (2016) e Zhou (2004) apontam: que imigrantes, ao chegarem ao país de destino, enfrentam diversas barreiras para se colocarem no mercado de trabalho formal, tais como falta de proficiência na língua, adaptação cultural e problemas de ordem migratória que, de acordo com a legislação do país de destino, podem colocar o imigrante em situação irregular ou ilegal.

\subsection{Redes de Apoio}

Durante a análise dos dados, ficou evidente como as redes de apoio formadas pelos imigrantes ao longo de suas trajetórias foram essenciais no acolhimento, na adaptação, na superação das barreiras linguísticas e culturais e na disponibilização de diversos tipos de recursos, tais como: recursos financeiros, máquinas e equipamentos, recursos de ordem emocional, entre outros. Como mencionado por Diniz et al. (2019) e Zhou (2004), o sentimento de solidariedade que permeia as imigrações, especialmente aquelas realizadas em contextos de grande vulnerabilidade, como a dos entrevistados, acaba se constituindo uma importante fonte de recursos de diversas ordens que contribuem para a atividade empreendedora dos imigrantes (Diniz et al., 2019; Sandberg et al., 2019; Zhou, 2004). Logo ao chegarem ao Brasil, os imigrantes receberam apoio de igrejas que os acolheram oferecendo moradia e de outras que ofereceram recursos financeiros pelo período de seis meses para pagamento de aluguel e de despesas com alimentação e com serviços essenciais como água e energia elétrica, conforme relatos abaixo, de Foad e Adullah:

\footnotetext{
"Voltei, esperei e eles falaram "tem uma igreja que você pode ficar sem pagar nada [...]Então eu cheguei aqui, o padre me recebeu falando árabe comigo, isso foi... brasileiro falando árabe... me mostrou onde eu vou dormir, falei muito obrigado." (Abdullah)
}

"A igreja arcou com todas as despesas por exemplo: aluguel, água, luz...e mais um valor para a gente comprar alimentos e viver." (Foad)

As redes sociais dos imigrantes, além de os receberem, auxiliaram orientando a respeito de como tirar documentos básicos no Brasil, tais como o registro geral (RG), o cadastro de pessoa física (CPF), bem como a solicitação de refúgio na Polícia Federal Brasileira. Já documentados, buscaram trabalho no mercado formal. Muitos não conseguiram por falta de proficiência na língua, conforme já identificado por Diniz et al. (2019) e Peroni et al. (2016). Outros conseguiram, porém sentiram-se explorados por empresários oportunistas, como o caso de Mouhamad, de 21 anos, que conseguiu emprego de chefe de cozinha em um restaurante libanês no centro do Rio de Janeiro, onde trabalhou por 7 meses. Assim que começou a trabalhar, o empregador o fez mudar de Jacarepaguá para a Tijuca para ficar mais perto do trabalho. Ele teve que pagar uma multa para rescindir o contrato de aluguel, a qual não estava no orçamento. Apesar de ter entregado sua carteira de trabalho para o empregador, ela nunca foi devolvida assinada e, após sete meses, em uma das vezes que solicitou sua devolução, o empregador a devolveu sem assinar e disse que ele estava demitido. Ganhava um salário e fazia longas jornadas no restaurante. Foi quando decidiu, com sua esposa, montar uma barraca de salgados.

Entre os refugiados localizados na região metropolitana de Belo Horizonte, as redes sociais ofereceram apoio relativo à moradia, ao ensino do idioma, à inserção no mercado de trabalho e ao processo empreendedor (Diniz et al., 2019; Correa \& Vale, 2017; Correa et al., 2018; Sandberg et al., 2019). Elian, de 30 anos, e John Eshak, de 24 anos, foram recebidos em Belo Horizonte em 2014 por Padre George. Eles moraram, durante algum tempo, no apartamento onde o padre abriga vários refugiados sírios. Por meio das redes sociais do padre, eles conseguiram aulas de português e trabalho em um restaurante de comida árabe muito famoso em Belo Horizonte, de propriedade de outro sírio. Elian e John vieram juntos da Síria e também trabalharam juntos no mesmo restaurante.

Os refugiados relataram que trabalharam duro, por horas e horas e sem folga. Elian se saiu muito bem no trabalho e, em seis meses, tornou-se gerente da loja do restaurante. Certo dia, Elian sentiu vontade de comer um sanduíche típico da Síria chamado kebab, mais conhecido como shawarma, e o não encontrou em nenhum estabelecimento em Belo Horizonte. Diante disso, percebeu a oportunidade de negócio e, junto com o amigo John Eshak, abriu uma pequena lanchonete chamada Sítio Sírio em uma região nobre de Belo Horizonte. A lanchonete fez muito sucesso e chegava a formar filas gigantescas para a compra de 
shawarma, de quibes e de falafel. O negócio foi crescendo e, atualmente, já são três lojas na região da Savassi, em Belo Horizonte, conforme relato abaixo:

"Quando cheguei no Brasil, procurei por Kebab e não encontrei. Pensei: isto não tem aqui! Desde quando cheguei eu pensava nisto, ou seja, desde fevereiro de 2014. Nem na Vila Árabe tinha, ele colocou agora na loja dele. Eu pensei neste sanduiche como uma oportunidade. Ele é original, do mesmo jeito que é feito lá, fazemos ele aqui. Começamos a juntar o dinheiro para abrir a primeira lanchonete." (Elian)

Esses achados confirmam o mencionado por Aldrich e Waldigner (1990), Diniz et al. (2019), Portes e Zhou (1992) e Zhou (2004), que relatam que indivíduos imersos em estruturas compostas por coétnicos favorecem o empreendedorismo étnico, haja vista que a falta de recursos e a falta de proficiência no idioma fazem com que os membros dessa estrutura se mobilizem oferecendo ajuda mútua, visando a adaptação, a diminuição das barreiras no país de destino, o acesso a recursos e a estratégias de gestão que facilitam o processo empreendedor.

De forma semelhante, podemos perceber como as redes sociais foram importantes para Foad, Yazan e Nizar, também imigrantes na região metropolitana de Belo Horizonte. Os refugiados chegaram ao Brasil no ano de 2014. Yazan e seu irmão Nizar foram recebidos por Padre George. Os irmãos também conseguiram se inserir no mercado de trabalho por meio dos contatos da rede social do padre. Yazan, por meio de uma indicação do padre George, foi trabalhar em um café. Lá, ele aprendeu fazer cappuccinos e vários tipos de doces.

Certo dia, um amigo do dono do café mencionou que era dono de um salão de beleza, e Yazan pediu uma oportunidade para seu irmão Nizar, dizendo que ele era cabelereiro na Síria e no Líbano e que havia penteado várias estrelas da televisão e do cinema árabe. Nizar fez um teste no salão e foi contratado. Logo fez muito sucesso e passou a ser conhecido pela alta sociedade mineira. Posteriormente, Nizar conseguiu levar Yazan para trabalhar no salão como ajudante, mas Yazan não se adaptou e conversou com a proprietária do salão. A proprietária perguntou, então, com o que ele gostava de trabalhar e Yazan disse que era com comida. Então, Dora, proprietária do salão, colocou-o para trabalhar na lanchonete que funcionava dentro do salão. A lanchonete pertencia à sua cunhada, e esta fazia e vendia salgados. Yazan passou a fazer os doces que havia aprendido no café e, com o tempo, foi aprendendo a fazer salgados. A dona da lanchonete passou por alguns problemas pessoais e doou $\mathrm{O}$ estabelecimento para Yazan, deixando todas as máquinas, os equipamentos e os estoques existentes. Yazan criou um novo sanduíche sírio chamado maazaaji, que significa "o amor e a alegria que alimentam a alma". O sanduíche tornou-se o carro chefe de sua lanchonete.

Os achados encontrados nas vivências de Yazan e Nizar demonstram a importância dos aspectos relativos ao capital social mencionados por Burt (2001), por Bourdieu (2002), por Coleman (1998) e por Sandberg et al. (2019), haja vista que cada membro da estrutura é detentor de capital social e que a interação do indivíduo com os demais membros the permite apropriar-se dos benefícios que circulam entre os membros da rede, sejam eles materiais ou simbólicos. A partir dessa interação, Yazan e Nizar encontraram oportunidades de novos empregos e de criar um novo negócio.

As redes sociais também se constituíram muito importantes para o processo empreendedor no caso de Nizar. Conforme mencionado, Padre George, que - recebeu, organiza uma rede de pessoas que frequentam sua paróquia para "apadrinhar" os refugiados. A pessoa que o apadrinhou, percebendo seu talento, propôs abrir um salão em sociedade com ele. Essa sociedade não deu certo, pois Nizar se sentia apenas como um empregado e não encontrou espaço para gerar sentimento de dono do estabelecimento.

No entanto, essa experiência representou o primeiro passo para que ele abrisse seu próprio salão na mesma região. Essa situação denota as dificuldades impostas por redes compostas por muitos laços fortes. Esse tipo de rede tende a aprisionar e a controlar seus membros, dificultando o acesso a novas informações e impedindo a inserção de novos membros à rede (Correa et al., 2018; Diniz et al., 2019; Granovetter, 1973, 1985, 1988, 2005b, 2008,).

Os relatos de Elian, de John Eshak, de Yazan e de Nizar corroboram com outros estudos que constataram que a estrutura das redes sociais de um indivíduo está relacionada de forma direta à sua 
capacidade de identificar oportunidades, como um emprego ou um negócio, e que os laços fracos são relevantes na disponibilização de diversos tipos de recursos e de informações relevantes (Coleman, 1988; Diniz et al., 2019; Granovetter, 1973, 1985, 1988, 2005b, 2008; Sandberg at al., 2019; Uzzi, 1977). Pode-se perceber também a atuação e o apoio das redes étnicas representadas pelo consulado sírio em Belo Horizonte por meio da organização do festival de comida e de cultura sírio-libanesa, em que os refugiados Gaby, Nabil e Kaled Tomeh têm participado e projetado seus negócios alimentícios desde o primeiro evento, realizado em 2018. Os refugiados ganharam maior visibilidade e divulgação dos produtos por eles comercializados. Adicionalmente, o festival resgata a cultura síria e libanesa por meio das comidas típicas, das músicas e das danças, tornando-se um ponto de encontro para os coétnicos e uma maneira de diminuir a saudade da terra natal. Esses achados destacam o sentimento de solidariedade presente entre coétnicos, constituindo uma importante fonte de diversos recursos que contribuem para a atividade empreendedora dos imigrantes (Diniz et al., 2019; Zhou, 2004).

\subsection{Recursos Disponibilizados no Processo Empreendedor}

De acordo com a literatura abordada, dois elementos importantes no processo empreendedor foram analisados: as redes sociais e o capital social. Segundo Correa e Vale (2017), Correa et al. (2018), Diniz et al. (2019), Mizruchi (2009) e Sandberg et al. (2019), as redes sociais são canais de transferência de recursos, materiais e imateriais, capazes de disponibilizar a seus membros o acesso a eles de forma diferenciada. Percebe-se, nos relatos dos entrevistados, que as estruturas sociais (redes) foram essenciais na promoção do seu processo empreendedor. Essa afirmação foi verificada em todos os casos analisados, especialmente entre os de Foad, de Elian, de John Eshak, de Yazan, de Nizar, de Nabil, de Armin, de Braheem, de Ali e de Abdullah, em que ficou evidente como as redes étnicas estabelecidas foram importantes no acolhimento desses refugiados, na diminuição das barreiras enfrentadas - especialmente as linguísticas e relativas à documentação - e na disponibilização de recursos que levaram os refugiados ao empreendedorismo (Diniz et al., 2019; Peroni et al., 2016).
No caso de Elian e de John Eshak, foi possível verificar como as redes étnicas contribuem com o processo empreendedor de coétnicos, conforme relatado por Zhou (2004). Ao serem empregados por outros sírios, os entrevistados aumentaram seu capital humano relativo ao conhecimento da culinária árabe e tiveram acesso a recursos financeiros entre os refugiados decorrentes do trabalho realizado no restaurante de um cóetnico. Foi verificada a atuação da rede étnica, nos casos de Yazan e de Nizar, por meio do apoio do Padre George, também de origem síria.

A estratégia utilizada pelo padre para ajudar os refugiados sírios por meio de apadrinhamento significou a ponte para que Nizar e Yazan se tornassem empreendedores, corroborando com Diniz et al. (2019), Granovetter (1985, 2008), Nazareno et al. (2019), Sandberg et al. (2019) e Zhou (2004), que mencionam que é no interior das estruturas sociais baseadas em redes interpessoais que são construídos os empreendimentos. No caso dos sírios Nabil, Armin, Braheem, Ali e Abdullah, localizados na região do Rio de Janeiro, verificou-se o apoio das redes étnicas no processo empreendedor por meio dos fornecedores de salgados como Taleb Yázigi, que repassa salgados com preços mais acessíveis aos coétnicos para que estes os revendam em quiosques espalhados na região central do Rio de Janeiro e na cidade de Niterói. As redes étnicas também foram ricas na disponibilização de recursos em relação à moradia e à alimentação e, principalmente, de recursos simbólicos afetivos, como mencionado por Abdullah ao relatar a importância de ter sido recebido por um padre que falava árabe. Esse fato trouxe conforto e segurança ao refugiado, gerando um sentimento de pertencimento e representando apoio emocional (Diniz et al., 2019; Peroni et al., 2016; Portes \& Zhou, 2012; Sandberg et al., 2019; Zhou, 2004).

Conforme mencionado por Burt (2001), duas estruturas de rede criam capital social: as redes fechadas (ou enclausuradas) e os "buracos estruturais". Para o autor, as primeiras podem gerar valor (capital social) por meio de elementos (atores) interconectados e as segundas por meio da "intermediação" (brokers). No caso do refugiado Foad, ficou explícita a atuação das redes enclausuradas, bem como a atuação de brokers (Burt, 2001). Foad converteu-se ao cristianismo ainda na Jordânia, antes de vir para o Brasil. Foi por meio de uma rede de contatos evangélica representada pela 
ONG brasileira denominada MAIS (Missão em Apoio à Igreja Sofredora) que Foad chegou ao Brasil.

Ao chegar, foi recebido pela Igreja Batista da Lagoinha, que ofereceu apoio como moradia e alimentação e que permitiu que ele vendesse seus salgados árabes após o término das reuniões. Podese considerar a rede de Foad com a igreja como uma rede enclausurada (fechada). Nesse tipo de rede, os indivíduos que a compõem estão bem conectados e bem informados, havendo uma maior padronização entre eles, resultando em maior coesão e eficiência (Correa \& Vale 2017; Diniz et al., 2019). Isso representa o capital social do enclausuramento. Esse ambiente de rede permite o estabelecimento de "laços de confiança" com maior consistência e em um curto período de tempo.

Foad também contou com o apoio de uma advogada local que soube de sua história e que resolveu ajudar. Por meio dessa advogada, o refugiado conheceu a família do Sr. Lorvandir, que o "adotou" como filho. Este ofereceu apoio emocional e tornou-se seu mentor no processo empreendedor. Forneceu máquinas e equipamentos para o aumento da produção e do estoque dos salgados e orientou-o acerca de como expor seus produtos em feiras de culinária na região metropolitana de Belo Horizonte.
Foi por meio da rede de contatos do Sr. Lorvandir que Foad conheceu seu sócio. Foad entrou na sociedade com o trabalho e com a experiência em restaurante árabe adquirida quando era chefe de cozinha na Síria e seu sócio entrou com o capital financeiro. A rede de Foad, formada a partir do contato com a advogada, pode ser evidenciada como um buraco estrutural. De acordo com Burt (2001), os buracos estruturais são encontrados em redes pouco conectadas e podem ter efeitos importantes sobre os fluxos dos diversos "bens" entre as redes, haja vista que nesse tipo de rede fluem conteúdos como informações, bens, capital, influência, emoções, bem como outros recursos essenciais aos usuários das estruturas da rede e que promovem o empreendedorismo.

\subsection{Proposições Teóricas}

Ao revisitar as teorias apresentadas no referencial teórico abordado neste trabalho, buscou-se, a partir das análises dos dados, confirmar ou refutar as proposições teóricas encontradas nos resultados. No Quadro 1 estão descritas as proposições e a discussão dos resultados. 
Tabela 2- Confirmação ou Refutação das Proposições Teóricas

\begin{tabular}{c|l|l}
\hline \multicolumn{1}{c|}{ Autores } & \multicolumn{1}{|c|}{ Proposição Teórica } & \multicolumn{1}{c}{ Discussão dos Resultados } \\
\hline Mialhe e Malheiros (2016) & $\begin{array}{l}\text { Organizações não governamentais } \\
\text { exercem importante papel de apoio na } \\
\text { recepção de imigrantes e refugiados. }\end{array}$ & $\begin{array}{l}\text { Os resultados sugerem a confirmação dessa } \\
\text { proposição. A Igreja Católica e ONGs evangélicas } \\
\text { exerceram papel fundamental na recepção e na } \\
\text { adaptação dos imigrantes e foram essenciais no } \\
\text { processo empreendedor dos pesquisados. }\end{array}$ \\
\hline Peroni et.al. (2016) & $\begin{array}{l}\text { As barreiras linguísticas e culturais } \\
\text { enfrentadas por imigrantes estimulam } \\
\text { iniciativas empreendedoras. }\end{array}$ & $\begin{array}{l}\text { Sugere-se a confirmação dessa proposição. Os } \\
\text { casos analisados evidenciaram que a barreira } \\
\text { linguística dificultou a inserção no mercado de } \\
\text { trabalho e, como meio de sobrevivência, } \\
\text { empreender representa a iniciativa viável. }\end{array}$ \\
\hline
\end{tabular}

Peroni et.al. (2016); Zhou Traços culturais herdados do país de Os resultados sugerem a confirmação dessa

(2004) $\quad$ origem facilitam iniciativas proposição. Todos os imigrantes sírios pesquisados empreendedoras. fizeram a opção pelo empreendedorismo étnico.

Cruz et al. (2018); Nazareno et Imigrantes têm propensão a empreender Os resultados sugerem a confirmação parcial dessa al. (2018); Peroni et.al. (2016); em áreas de enclave étnico, pois as redes proposição. Os imigrantes sírios não estão Zhou (2004) étnicas podem fornecer diversos tipos de recursos como, por exemplo, capital financeiro. envolvidos em enclaves étnicos. No entanto, as redes étnicas estabelecidas apoiaram e foram fontes de recursos que contribuíram no processo da criação de negócios.

Os empreendedores étnicos mantêm Os resultados sugerem a confirmação parcial dessa relacionamentos com os coétnicos proposição. Entre os refugiados, verificou-se o inclusive com envolvimento emocional. O relacionamento com outros sírios. No entanto, não relacionamento com os coétnicos auxilia foi identificada disponibilização de recursos na solução dos problemas e ajuda os emocionais que tenham sido utilizados na solução coétnicos a se estabelecerem no de problemas relacionados ao processo mercado concorrente. empreendedor.

Correa et al. (2018); Diniz et al. (2019); Granovetter (1985, As redes sociais são ferramentas 2005b); Sandberg et al. (2019) importantes e essenciais para o desenvolvimento do empreendedorismo.

Em todos os casos analisados, verificou-se que as redes sociais foram decisivas no desenvolvimento do empreendedorismo dos pesquisados, seja por meio da disponibilização de recursos financeiros, emocionais ou de informações relevantes.

Correa \& Vale (2017); Correa As redes formadas por laços fracos Sugere-se a confirmação dessa proposição. Na at al. (2018); Diniz et al. favorecem a difusão de conhecimento, trajetória dos refugiados, verificou-se que os laços (2019); Granovetter (1973, agregam novas informações, facilitam o fracos foram responsáveis por informações e por 1985, 2005b); Sandberg et al acesso a diversos tipos de recursos. $\quad$ acesso a recursos que facilitaram a atividade (2019)

Correa \& Vale (2017); Correa Os laços fortes exercem grande influência at al. (2018); Diniz et al. nas relações econômicas. São fontes de (2019); Granovetter (1973, capital financeiro e mão de obra de baixo 1985, 2005b); Sandberg et al. custo. As relações são baseadas na (2019)

confiança. Porém, as informações desse tipo de laço são redundantes. empreendedora.

Confirma-se essa proposição. Verificou-se, nas redes de Yazan e Nizar, maior quantidade de laços fortes do que nos demais casos. No caso de Yazan, os laços fortes são a sustentação emocional do refugiado e mão de obra na produção dos alimentos. Não foram verificadas, nos casos analisados, informações de relevância que tenham sido obtidas por meio de laços fortes.

Aldrich e Waldinger (1990); As redes étnicas são fontes de capital Os resultados da pesquisa confirmaram essa Diniz et al. (2019); Portes e financeiro, mão de obra, entre outros, e proposição. Em todos os casos analisados, as redes Zhou (1992); Sandberg permitem o desenvolvimento de étnicas forneceram capital financeiro, capital físico (2019); Zhou (2004) competências empreendedoras e o e mão de obra que viabilizaram o negócio. crescimento empresarial.

\section{Fonte: Elaborado pelos autores}




\section{Considerações Finais}

Este artigo teve como objetivo analisar como redes étnicas apoiam e influenciam na criação de novos negócios. Para isso, foi realizada uma pesquisa exploratória com 24 imigrantes sírios, refugiados e solicitantes de refúgio nas cidades do Rio de Janeiro, Belo Horizonte e sua região metropolitana para promover a reflexão sobre as condições institucionais e de acolhimento do país na tomada de decisão para a criação de negócios étnicos e a relação desses negócios com diferentes públicos. Os resultados apontam que as redes étnicas influenciaram e disponibilizaram variados tipos de recursos que contribuíram com o processo empreendedor dos refugiados, especialmente os localizados na região metropolitana de Belo Horizonte (Correa \& Vale, 2017; Correa et al., 2018; Diniz et al., 2019; Nazareno et al., 2019; Sandberg et al., 2019).

No entanto, entre os refugiados localizados no Rio de Janeiro, não foi possível identificar o estabelecimento de uma rede de apoio étnico bem estruturada que estimulasse a criação e a expansão de novos negócios e a identificação de oportunidades. Os resultados reforçaram a importância da atividade empreendedora de imigrantes na geração de renda, principalmente em negócios relacionados à sua cultura de origem (Diniz et al., 2019; Sandberg et al., 2019). Um achado importante da pesquisa realizada com os refugiados no Rio de Janeiro foi a apoio recebido da prefeitura, que cadastrou e permitiu que os imigrantes pudessem vender os salgados em barracas situadas em diversos pontos da cidade.

Por outro lado, o apoio recebido por ONGs e igrejas apareceu como muito importante no acolhimento e na regularização dos imigrantes perante os órgãos brasileiros e esses atores proporcionaram o acesso a recursos emocionais e materiais que foram essenciais no processo empreendedor, conforme mencionado no estudo de Diniz et al. (2019) e Mialhe e Malheiros (2016). Os resultados confirmaram o modelo teórico utilizado na análise dos dados, em que as estruturas sociais (redes) étnicas e não étnicas são detentoras de um volume significativo de capital social, e em que este permite aos membros da estrutura o acesso a diversos tipos de capital que promovem o processo empreendedor de refugiados (Correa \& Vale, 2017; Correa et al., 2018; Diniz et al., 2019; Granovetter, 1973, 1985, 2005b; Sandberg et al., 2019).

Finalmente, este artigo contribui para o debate do empreendedorismo imigrante realizado por refugiados em solo brasileiro, apontando para a importância e para os efeitos das redes sociais e do capital social no desenvolvimento de novos negócios. Como contribuição teórica, este estudo proporciona maior compreensão sobre a dinâmica local do empreendedorismo imigrante, das redes sociais e do capital social. Amplia os modelos conceituais e teóricos estabelecidos no estudo do processo empreendedor imigrante. Como contribuição social, este estudo revela a importância da atividade empreendedora de imigrantes na geração de renda e no desenvolvimento da economia local. Os achados revelam a necessidade de políticas públicas que apoiem o empreendedorismo imigrante no Brasil.

Como limitação da pesquisa, apontou-se o caráter qualitativo, não sendo possível a generalização dos resultados. No entanto, o estudo fornece informações abrangentes que podem ser aplicadas para analisar situações semelhantes que envolvam o empreendedorismo de imigrantes. Sendo assim, sugere-se, para pesquisas futuras, verificar se há relação entre algumas dimensões, como por exemplo tempo na cidade e novas oportunidades de negócio. Sugere-se, também, o aprofundamento de estudos sobre redes étnicas melhor estruturadas, a fim de verificar como elas atuam no processo empreendedor de imigrantes.

\section{Referências}

Aldrich, H.E. \& Waldinger, R. (1990). Ethnicity and entrepreneurship. Annual Review of Sociology, 16(1), 111-135.

Bardin, L. (2006). Análise de conteúdo (L. de A. Rego \& A. Pinheiro, Trads.). Lisboa: Edições 70. (Obra original publicada em 1977). 
Bourdieu, P. (2002). The forms of capital. Biggart, N. (org). Readings in economic sociology. MaldenMA: Blackwell, 280-291.

Burt, N., Cook, K.S. \& Burt, R.S. (Eds.). (2001). Social capital: Theory and research. Transaction Publishers.

Brasil. (2017). Refúgio em números. In. Ministério da Justiça e Segurança Pública. CONARE. Disponível em: $\quad<\quad$ https://www.acnur.org/portugues/wpcontent/uploads/2018/04/refugio-emnumeros 1104.pdf >> Acesso em: 21 de set. de 2019.

Coleman, J. S. (1988). Social capital in the creation of human capital. American journal of sociology, 94, S95-S120.

Corrêa, V. S., \& Vale, G. M. V. (2017). A Dinâmica e a influência das redes sociais para o sucesso empreendedor. Revista Organizações em Contexto, 13(25), 1-19.

Corrêa, V. S., Vale, G. M. V., \& Pinto, M. D. R. (2018). Acoplamento e desacoplamento sociais: Pastores como empreendedores. RAE-Revista de Administração de Empresas, 58(2), 188-200.

Creswell, J.W. (2013). Etapas na condução de um estudo de métodos mistos acadêmicos.

Cruz, E. P., Falcão, R. P. Q., \& Barreto, C. R. (2018). Exploring the evolution of ethnic entrepreneurship: the case of Brazilian immigrants in Florida. International Journal of Entrepreneurial Behavior \& Research, 24(5), 971-993.

Dabić, M., Vlačić, B., Paul, J., Dana, L. P., Sahasranamam, S., \& Glinka, B. (2020). Immigrant entrepreneurship: A review and research agenda. Journal of Business Research, 113, 25-38.

Denzin, N.K. \& Lincoln, Y.S. (Eds.). (2011). The Sage handbook of qualitative research. Sage.

Diniz, G.C.S., Guimarães, L.O. \& Fernandes, D.M. (2019). Empreendedorismo imigrante e étnico: o papel das redes sociais no processo empreendedor de imigrantes sírios no Brasil. Revista Eletrônica de Negócios Internacionais, 14(2).
Eisenhardt, K.M. (1989). Building theories from case study research. Academy of management review, 14(4), 532-550.

Gioia, D. A., Corley, K. G., \& Hamilton, A. L. (2013). Seeking qualitative rigor in inductive research: Notes on the Gioia methodology. Organizational research methods, 16(1), 15-31.

Granovetter, M. (1973). The strength of weak tiés. American Journal of Sociology, 78(6), 1360-1380.

Granovetter, M. (1985). Economic action and social structure: the problem of embeddedness. American Journal of Sociology, 91, 481-510.

Granovetter, M. (1998). A network theory revisited. Sociological Theory, 1, 201-233.

Granovetter, M. (2005b). The impact of social structure on economic. Journal of Economic Perspectives, 19(1), 33-50.

Granovetter, M. (2008). Sociologie économique. Paris: Seuil.

Gurău, C., Dana, L. P., \& Light, I. (2020). Overcoming the liability of foreignness: A typology and model of immigrant entrepreneurs. European Management Review, 17(3), 701-717.

Haas, H. (2011). The determinants of international migration: Conceptualising policy, origin and destination effects. International Migration Institute University of Oxford, Working papers 32.

Mialhe, J. L., \& Malheiro, K. C. (2016). Os refugiados no Brasil e as organizações não governamentais. Revista de Direitos Humanos em Perspectiva, 2(1), 37-55.

Mizruchi, M.S. (2009). Análise de redes sociais: avanços recentes e controvérsias atuais.

Nazareno, J., Zhou, M. \& You, T. (2019). Global dynamics of immigrant entrepreneurship: Changing trends, ethnonational variations, and reconceptualizations. International Journal. 
Neto, A. C., Versiani, F., Pellizari, K., Mota-Santos, C., \& Abreu, G. (2020). Latin American, African and Asian immigrants working in Brazilian organizations: facing the language barrier Imigrantes Latinoamericanos, Africanos e Asiáticos trabalhando em Organizações Brasileiras: enfrentando a barreira do idioma. E\&G Economia e Gestão, Belo Horizonte, v. 20, n. 55, Jan./Abr. 2020.

Onu (2018). Sete fatos sobre a guerra na Síria. Disponível em: https://nacoesunidas.org/sete-fatossobre-a-guerra-na-siria/ - Acesso em: 21 de set. de 2019.

Portes, A. \& Zhou, M. (1992). Gaining the upper hand: Economic mobility among immigrant and domestic minorities. Ethnic and Racial Studies, 15(4), 491-522.

Portes, A. \& Zhou, M. (2012). Transnationalism and development: Mexican and Chinese immigrant organizations in the United States. Population and Development Review, 38(2), 191-220.

Peroni, C., Riillo, C.A., \& Sarracino, F. (2016). Entrepreneurship and immigration: evidence from GEM Luxembourg. Small Business Economics, 46(4), 639-656.

Sandberg, S., Immonen, R., \& Kok, S. (2019). Refugee entrepreneurship: taking a social network view on immigrants with refugee backgrounds starting transnational businesses in Sweden. International Journal of Entrepreneurship and Small Business, 36(1-2), 216-241.
Shinnar, R.S., \& Zamantılı Nayır, D. (2019). Immigrant Entrepreneurship in an Emerging Economy: The Case of Turkey. Journal of Small Business Management, 57(2), 559-575.

Vale, G.M.V., Corrêa, V.S. \& dos Reis, R.F. (2014). Motivações para o empreendedorismo: necessidade versus oportunidade? RAC-Revista de Administração Contemporânea, 18(3), 311-327.

Urban, B. (2011). Entrepreneurial networking differences: An ethnic in-group and out-group analysis. SA Journal of Industrial Psychology, 37(1), 01-14.

Uzzi, B. (1997). Social structure and competition in interfirm network: The paradox of embeddedness. Administrative Science Quarterly, 42, 35-67.

Wasserman, S. \& Faust, K. (1999) Social Network Analysis: Methods and Applications. Cambridge: Cambridge University.

Yin, R.K. (2005). Estudo de caso: planejamento e métodos. (2.ed.). Porto Alegre: Bookman.

Zhou, M. (2004). Revisiting ethnic entrepreneurship: convergencies, controversies, and conceptual advancements. International Migration Review, 38(3), 1040-1074.

Zhou, M., \& Liu, H. (2015). Empreendedorismo transnacional e integração de imigrantes: Novos imigrantes chineses em Singapura e nos Estados Unidos. Emerald Group Publishing Limited.

Gislene Cordeiro da Silva Diniz - Pontifícia Universidade Católica de Minas Gerais - PUC, Minas Gerais, (Brasil). E-mail: gislenecordeirodiniz@gmail.com Orcid id: https://orcid.org/0000-0002-7509-8263

Liliane de Oliveira Guimarães - Pontifícia Universidade Católica de Minas Gerais - PUC, Minas Gerais, (Brasil). E-mail: lilianeog@pucminas.br Orcid id: https://orcid.org/0000-0002-3346-2207

Roberto Pessoa de Queiroz Falcão - Universidade Federal Fluminense - UFF, Rio de Janeiro, (Brasil). E-mail: robertopqfalcao@gmail.com Orcid id: https://orcid.org/0000-0002-8125-0938

Eduardo Picanço Cruz - Universidade Federal Fluminense - UFF, Rio de Janeiro, (Brasil). E-mail: epicanco@id.uff.br Orcid id: https://orcid.org/0000-0003-4484-3256 
Gislene Cordeiro da Silva Diniz, Liliane de Oliveira Guimarães, Roberto Pessoa de Queiroz Falcão \& Eduardo Picanço Cruz

Pontifícia Universidade Católica de Minas Gerais - PUC, Minas Gerais, (Brasil)

Universidade Federal Fluminense - UFF, Rio de Janeiro, (Brasil)

ARTICLE DETAILS
Article history:
Received: 16 august 2020
Accepted: 29 march 2021
Available online october: 27 th 2021
Double Blind Review System
Scientific Editor
Ilan Avrichir

\section{Keywords}

Immigrant entrepreneurship

Syrians

Social Network

Social Capital

\section{ABSTRACT}

Objective: The objective of this work is to analyze how ethnic networks support and influence the creation of new businesses.

Method: Qualitative research and multiple case study method. Semi-structured interviews with 24 Syrian refugees, established in the city of Rio de Janeiro, Belo Horizonte and its metropolitan region. The interviews were conducted between August 2017 and May 2019.

Main results: The results show that ethnic networks influenced and made available resources that contributed to the entrepreneurial process. The importance of the entrepreneurial activity for the generation of income of the refugees was verified, mainly in businesses related to their culture of origin. The findings confirmed that social structures hold a significant volume of social capital, which allows access to different types of resources that promote the entrepreneurial process.

Relevance / originality: This article contributes to the debate on immigrant entrepreneurship carried out by refugees on Brazilian soil, pointing to the importance and effects of social networks and social capital in the development of new businesses.

Theoretical / methodological contributions: Greater understanding of the local dynamics of immigrant entrepreneurship, of the social networks and of the social capital. It expands the conceptual and theoretical models established in the study of the immigrant entrepreneurial process.

Social contributions: Importance of entrepreneurial activity for immigrants in generating income and developing the local economy. The findings reveal the need for public policies that support immigrant entrepreneurship in Brazil. 
Gislene Cordeiro da Silva Diniz, Liliane de Oliveira Guimarães, Roberto Pessoa de Queiroz Falcão \& Eduardo Picanço Cruz

Pontifícia Universidade Católica de Minas Gerais - PUC, Minas Gerais, (Brasil)

Universidade Federal Fluminense - UFF, Rio de Janeiro, (Brasil)

\section{DETALLES DEL ARTÍCULO}

\section{Historia del Artículo:}

Recibido: 16 de agosto de 2020

Aceptado: 29 de marcha de 2021

Disponible en línea: 27 de octubre 2021

\section{Double Blind Review System}

Editor Científico

Ilan Avrichir

\section{Palabras-clave:}

Emprendimiento de Inmigrantes

Sírios

Redes Sociales

Capital Social

\section{RESUMEN}

Objetivo: El objetivo de este trabajo es analizar cómo las redes étnicas apoyan e influyen en la creación de nuevos negocios.

Método: Investigación cualitativa y método de estudio de casos múltiples. Entrevistas semi-estructuradas a 24 refugiados sirios, establecidos en la ciudad de Río de Janeiro, Belo Horizonte y la región metropolitana. Las entrevistas se realizaron entre agosto de 2017 y mayo de 2019.

Resultados principales: Los resultados muestran que las redes étnicas influyeron y pusieron a disposición recursos que contribuyeron al proceso empresarial. Se verificó la importancia de la actividad empresarial para la generación de ingresos de los refugiados, principalmente en negocios relacionados con su cultura de origen. Los hallazgos confirmaron que las estructuras sociales contienen un volumen importante de capital social, lo que permite el acceso a diferentes tipos de recursos que promueven el proceso empresarial.

Relevancia / originalidad: Este artículo contribuye al debate sobre el emprendimiento inmigrante realizado por refugiados en suelo brasileño, señalando la importancia y efectos de las redes sociales y el capital social en el desarrollo de nuevos negocios.

Aportes teóricos / metodológicos: Mayor comprensión de las dinámicas locales de emprendimiento inmigrante, redes sociales y capital social. Amplía los modelos conceptuales y teóricos establecidos en el estudio del proceso empresarial inmigrante.

Contribuciones sociales: Importancia de la actividad empresarial para los inmigrantes en la generación de ingresos y el desarrollo de la economía local. Los hallazgos revelan la necesidad de políticas públicas que apoyen el espíritu empresarial de los inmigrantes en Brasil.

\section{Como citar este artigo:}

Diniz, G. C. da S., Guimarães, L. de O., Falcão, R. P. de Q., \& Cruz, E. P. (2022). Redes de Imigração Síria no

Brasil e Criação de novos Negócios. Internext, 17(1), 01-21. https://doi.org/10.18568/internext.v17i1.624 